Makalenin Türü / Article Type Geliş Tarihi / Date Received Kabul Tarihi / Date Accepted Yayın Tarihi / Date Published
: Araştırma Makalesi / Researh Article

: 25.03.2019

$: 15.10 .2019$

:31.12.2019

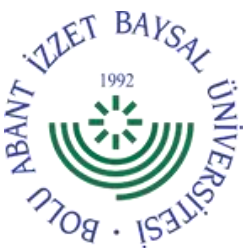

\title{
ORTAOKUL TÜRKÇE DERSİ ÖĞRETMEN KILAVUZ KITTAPLARININ KULLANILMASI VE KULLANILMAMASINA İLIŞKİN BİR DURUM ÇALIŞMASI
}

\author{
Üzeyir SÜĞÜMLÜ , Hasan Hüseyin MUTLU², Enes ÇiNPOLAT ${ }^{3}$
}

\section{$\ddot{O} \mathbf{Z}$}

Araştırma, uygulamadan kaldırılan Türkçe dersi öğretmen kılavuz kitaplarının derse hazırlık, ders işleme süreci, ölçme ve değerlendirme açılarından olumlu ve olumsuz yönleri ile kılavuz kitapların kullanılmaması durumunun ortaya çıkardığı olumlu ve olumsuz yönlerinin belirlenmesi amacıyla gerçekleștirilmiştir. Araştırma, nitel araştırma desenlerinden durum çalıșması ile yürütülmüştür. Araştırmanın çalışma grubunu, 2018-2019 Eğitim-Öğretim Yılı Güz Yarıyılı'nda Ordu ilinde görev yapan 18 Türkçe öğretmeni oluşturmaktadır. Araştırmanın veri toplama aracı, yarı yapılandırılmış görüşme formudur. Yarı yapılandırılmış görüşme formu yoluyla elde edilen veriler, MAXQDA 12 nitel veri analizi programına aktarılmış ve içerik analizi tekniği kullanılarak çözümlenmiştir. Çözümlenen veriler, program aracılığıyla elde edilen görsellerle sunulmuş ve yorumlanmıștır. Araştırma ile kılavuz kitapların ders hazırlı̆̆ 1 açısından dersi planlama ve ders hazırlığı yapma yönünden yararlı olduğu ancak kolaycılığa alıştırması yönünden olumsuzluk oluşturduğu; ders işleme süreci açısından derse hâkimiyetin sağlanması, planlama yapılabilmesi ve kolaylık oluşturması yönlerinden katkılarının olduğu ancak öğretmenleri sınırlaması yönüyle olumsuzluk oluşturduğu; ölçme ve değerlendirme açısından yardımcı olması ve öğretmenin işini kolaylaştırması, dönüt vermesi ve takip yapabilmesi yönlerinden katkılarının olduğu ancak yeterli görülmemesinin olumsuzluk oluşturduğu; kılavuz kitaplarının kullanılmamasının esneklik tanıma ve araştırmaya yönlendirme açısından katkılarının olduğu ancak iş yükünün artması, öğretim birliğinin sağlanamaması, öğretmen rehberliğinin ortadan kalkması ve öğretmenin derse hazırlıklı gelmemesi yönlerinden olumsuzluk oluşturduğu sonuçlarına ulaşılmıştır.

Anahtar Kelimeler: Öğretmen kılavuz kitapları, derse hazırlık, ders işleme süreci, ölçme ve değerlendirme.

\section{A CASE STUDY RELATED TO NON-USE AND USE OF SECONDARY SCHOOL TURKISH COURSE TEACHER GUIDEBOOKS}

\section{ABSTRACT}

The research was carried out on Turkish course teachers' guidebooks, which were removed from the curriculum with the aim of determining the positive and negative aspects of the guidebooks in terms of preparation for the course, course process, measurement and evaluation, and their removal from use.. The research was conducted using a case study of the qualitative research methods. The study group consisted of 18 Turkish teachers working in the province of Ordu in the Fall Semester of 2018-2019 Academic Year. A semi-structured interview form was used to collect the data of the research. Data obtained through a semi-structured interview form were transferred to the MAXQDA 12 qualitative data analysis program and have been analyzed through using content analysis technique. The analyzed data are presented and interpreted with the visuals obtained through the program. In terms of course preparation, it is concluded that the guidebooks are useful in terms of planning and preparing lessons, but they negatively lead to the expectation that everything was to be handed to them on a silver platter. In terms of course handling process, it is concluded that they have contributed to the lesson, they help make planning more convenient yet at the same time they limit teachers. In terms of measurement and evaluation, it was seen that the guidebooks contributed to facilitating the teacher's job, giving feedback and follow-up, but it was concluded that it was insufficient. It has been concluded that not using the guidebooks contributes to flexibility and leading to research, but it has negative effects such as increased workload, lack of teaching unity.

Keywords: Teacher guidebooks, course preparation, course process, measuring and evaluation.

\footnotetext{
${ }^{1}$ Ordu Üniversitesi, Ë̆itim Fakültesi, Dr. Öğr. Üyesi, u.sugumlu@gmail.com, 는ttps://orcid.org/0000-0003-2135-5399

2 Ordu Üniversitesi, Eğitim Fakültesi, Dr. Öğr. Üyesi, hasanhuseyinmutlu@hotmail.com, 는 https://orcid.org/0000-0002-9082-709X

${ }^{3}$ Ordu Üniversitesi, Sosyal Bilimler Enstitüsü, Arş. Gör., enescinpolat@gmail.com, 는 https://orcid.org/0000-0002-3411-4300
} 


\title{
1. GİRIŞ
}

Cumhuriyetin ilan edilmesiyle yeniden yapılanma sürecinde değişimin en çok yaşandığı alanlardan biri de eğitimöğretim olmuştur. Eğitimin temel unsurlarından biri olan öğretim programlarının günümüze kadar sürekli bir değişim ve gelişim içinde olduğu uygulamaya konulan öğretim programlarından anlaşılmaktadır. 1924'ten başlayarak 2005'e değin 1924, 1926, 1936, 1948, 1968 ve 1981 ilkokul/ilköğretim I. kademe Türkçe öğretim programları; 1924, 1927, 1938, 1949, 1970 ve 1981 ortaokul/II. kademe Türkçe öğretim programları uygulanagelmiştir (Temizyürek ve Balcı, 2015). 2000'li yıllara gelindiğinde gelişen teknoloji ve ortaya çıkan bilimsel çalışmalar, yeni bir öğretim programının gerekliliğini de ortaya koymuştur. Bu bağlamda, 23 y1l uygulamada kalan ve davranışçı yaklaşımı temel alan 1981 öğretim programının yerine tamamen değişen ve yapılandırmacı yaklaşımı model alan 2004-2005 ilköğretim I. ve II. kademe Türkçe öğretim programları uygulamaya konulmuştur. Bu yeni programla birlikte hedef/davranış kavramı yerini amaç/kazanıma bırakmış; ders kitabı, öğrenci çalışma kitabı ve öğretmen kılavuz kitabı gibi basılı materyaller, eğitim-öğretim sürecine dâhil olmuştur. Bu yeni öğretim programının uygulanmasında ise öğretmen kılavuz kitapları önemli bir rol üstlenmiştir.

Yeni öğretim programının uygulama sürecinde öğretmenlerin rolünü ayrıntılı bir şekilde açıklayan kılavuz kitaplar, ders planı niteliği de taşımakta ve öğretmenlere bir dersin nasıl işleneceği konusunda rehberlik yapmaktadır. 2005 yılında 2551 sayılı Tebliğler Dergisi’nde yayımlanan Millî Eğitim Bakanlığı Eğitim ve Öğretim Çalışmalarının Planlı Yürütülmesine İlişkin Yönergesinin "Ders Planı” başlıklı 12. maddesinde, "Öğretmen kılavuz kitabı bulunan derslerde, kılavuz kitap, ders plânı yerine kullanılır." denilmiştir. Bununla birlikte 2012 yılında 28409 sayılı Resmî Gazete'de yayımlanan Millî Eğitim Bakanlığı Ders Kitapları ve Eğitim Araçları Yönetmeliğinin öğretmen kılavuz kitaplarının hazırlanması ile ilgili bölümünde bu kitapların nitelikleri yönetmeliğin 10. maddesinde şu şekilde belirtilmiştir:

\begin{abstract}
“Öğretmen kılavuz kitabında konuların işlenişinde ulaşılmak istenen kazanımlar/hedefler belirtilir. Eğitim ve öğretim programlarında yer alan kazanım/amaç ve açıklamalar doğrultusunda öğrencilere bilgi, beceri, tutum ve davranıșların kazandırılmasında öğretmene yardımcı olacak ve öğretmeyi kolaylaştıracak bilgi, örnek ve uygulamalara yer verilir. Bilgi, beceri, tutum ve davranışlar ile değerlerin öğrencilere kazandırılmasında kullanılabilecek araç-gereçle birlikte öğretim yöntem ve teknikleri ile ayrıca; konu ile ilgili zaman analizine ve konunun işleniş planına, öğretmenin konu ile ilgili yapacağ ön hazırlıklara, konuya girerken daha önce işlenen konularla ilişkisini sağlayacak ve öğrencinin ilgisini çekecek hatırlatmalara, sorulara ve benzeri unsurlara, ders kitabında yer alan ve açıklama gerektiren şekil, şema, çizelge ve benzeri yardımcı unsurlara, yer verilir. Öğrencileri araştırmaya, günlük yaşamda karşılaşılan çeşitli sorunlara çözüm üretmeye yöneltecek ödev, proje ve benzeri örnek çalışmalara yer verilir. Konuların sonunda, gerekli görülmesi halinde verilen kavramlarla ilgili sözlük bulunur."
\end{abstract}

Yönetmelikten anlaşılacağı üzere kılavuz kitaplar, öğretmenlerin programı ne şekilde uygulaması gerektiğini açık bir şekilde ifade etmektedir. Bununla birlikte 2015 Türkçe Dersi 6. Sınıf Öğretmen Kılavuz Kitabı'nın giriş bölümünde; dersin amaçları, becerileri, kazanımları, etkinlikleri ve ölçme araçları ile ilgili bilgiler ayrıntılı olarak belirtilmiş ve bunların öğretmene dersin işleniş sürecinde yardımcı olacağı vurgulanmıştır (MEB, 2015). Buradan hareketle ilk kez 2004 yılında yeni bir anlayışla uygulamaya konulan öğretim programı ile öğretmen kılavuz kitaplarının öğretmenlerin yeni programı özümsemesini, programın uyum sürecinde ortaya çıkabilecek olası sorunların önüne geçilmesini veya belirsizliğe yol açacak durumların önlenmesini amaçlandığı söylenebilir. Mevcut öğretmenlerin bir önceki program temelinde yetiştiği göz önüne alındığında programın uygulanması eş zamanlı olarak görev yapan öğretmenlerin bilgilendirilmesi gerekliliğini ortaya çıkarmıştır.

2005 yılından 2017 yılına değin yürürlükte kalan öğretmen kılavuz kitapları, 2018-2019 eğitim-öğretim yılında kullanımdan kaldırılmıştır. Göçer ve Aktürk’e (2015) göre öğretmen kılavuz kitapları öğretmenlerin derse hazırlık, planlama, sınıf içi ders işleme sürecinde ders kitabını doğru ve verimli kullanabilmeleri için gereklidir. Ayrıca kılavuz kitaplar öğrenciye rehberlik etme sürecini de kolaylaştırır. Ayvacı ve Er-Nas'a (2009) göre de öğretmen kılavuz kitaplarının öğretme-öğrenme sürecinde yer alan etkinliklerinin uygulanmasında, değerlendirilmesinde ve geliştirilmesinde büyük önemi vardır. Göçer (2011), öğretmen kılavuz kitaplarının olumlu yanlarıyla birlikte birtakım olumsuzlukları da beraberinde getirdiğini belirtmektedir. Araştırmanın çalışma grubunu oluşturan öğretmenlerin \%70 gibi önemli bir bölümünün programdaki değişiklikleri ders kitapları ve kılavuz kitaplardan izledikleri, bu nedenle kılavuz kitaplara bağımlı olduklarını ortaya koymuştur. Bu durumun öğretmenlerin öğretim programını takip etmelerini, programı bir bütün olarak anlama ve algılamalarını güçleştirdiği söylenebilir.

Her öğretim programı ve bu program çerçevesinde geliştirilen öğretim materyalleri, programın uygulandı ̆̆ coğrafya, demografik yapı, kültürel ve bireysel özeliklere göre esnek olarak tasarlanmakta veya programın uygulayıcısı olan öğretmenlerin programı bu koşullara göre uyarlaması gerekmektedir. Bu açıdan bakıldığında ögretmen kılavuz kitaplarının kaldırılması, sıkı sıkıya bağlılı̆̆ı ortadan kaldırdığ1 için olumlu olarak görülebilir ancak bu kitapların eğitim-öğretim sürecini kolaylaştırdığı, öğretmene rehberlik ettiği ve daha planlı bir öğretim süreci sunduğunu da bir gerçektir. 


\subsection{Araştırmanın Amacı}

Araştırma, ortaokul Türkçe dersi öğretmen kılavuz kitaplarının kullanılmasının derse hazırlık, ders işleme süreci, ölçme ve değerlendirme açılarından oluşturduğu olumlu ve olumsuz durumlarla kılavuz kitapların kullanılmamasının ortaya çıkardığı olumlu ve olumsuz durumların belirlenmesi amacıyla gerçekleştirilmiştir. Araştırmanın alt amaçları şu şekildedir:

1. Ortaokul Türkçe dersi öğretmen kılavuz kitaplarının Türkçe öğretmenlerine derse hazırlık yönüyle oluşturduğu olumlu ve olumsuz durumları belirlemek.

2. Ortaokul Türkçe dersi öğretmen kılavuz kitaplarının Türkçe öğretmenlerine ders işleme süreci yönüyle oluşturduğu olumlu ve olumsuz durumları belirlemek.

3. Ortaokul Türkçe dersi öğretmen kılavuz kitaplarının Türkçe öğretmenlerine ölçme ve değerlendirme yönüyle oluşturduğu olumlu ve olumsuz durumları belirlemek.

4. Ortaokul Türkçe dersi öğretmen kılavuz kitaplarının kullanılmamasının (güncel durum) Türkçe öğretmenlerine derse hazırlık, ders işleme süreci, ölçme ve değerlendirme yönleriyle oluşturduğu olumlu ve olumsuz durumları belirlemek.

\subsection{Araştırmanın Önemi}

Alanyazında öğretmen kılavuz kitaplarına yönelik çeşitli araştırmaların yapıldı̆̆ı görülmektedir (AlkışKüçükaydın ve İşcan, 2017; Bağcı, 2010; Göçer ve Aktürk, 2015; Göçer ve Sayın, 2014; Kurudayığlu ve ÖrgeYaşar, 2014; Yaylı ve Solak, 2014). Yapılan araştırmalar, MEB'in kendi hazırladığı ve farklı yayınevleri tarafından hazırlanan öğretmen kılavuz kitaplarının çeşitli açılardan değerlendirmelerini içermektedir. Bu araştırma, ortaokul Türkçe dersi öğretmen kılavuz kitaplarının uygulamadan kaldırılması sonucu, kılavuz kitapların kullanılması ve kullanılmaması durumlarına yönelik Türkçe öğretmenlerinin kitapları derse hazırlık, ders işleme süreci, ölçme ve değerlendirme yönleriyle değerlendirmelerini kapsamaktadır. Konu ile ilgili yapılan araştırmalara bakıldığında, bu araştırmanın kapsamının yapılan araştırmalardan farklı olduğu anlaşılmaktadır. Yeni oluşan bir durumun incelenmesi ve konunun güncel olması, araştırmanın önemini göstermektedir.

\section{YÖNTEM}

\subsection{Araştırma Deseni}

Araştırma, nitel araştırma desenlerinden durum çalışması ile yürütülmüştür. Durum çalışması, sınırlı bir sistemin derinlemesine betimlenmesi ve incelenmesidir (Merriam, 2013). Durum çalışması verilerin toplanması, düzenlenmesi, çözümlenmesi ve yorumlanmasında özel bir yöntem oluşturur ve bu nedenle bir çözümleme ve yorumlama sürecini temsil eder (Patton, 2002). Türkçe dersi öğretmen kılavuz kitaplarının 2018-2019 EğitimÖğretim Yılı'nda uygulamadan kaldırılması durumu, Türkçe öğretmenlerinin görüşleriyle incelenmiştir.

\section{2. Çalışma Grubu}

Araştırmanın çalışma grubunu, Ordu ilinde Millî Eğitim Bakanlığına bağlı okullarda 2018-2019 Eğitim-Öğretim Yılı Güz Yarıyılı'nda (1. Dönem) görev yapan ve çalışmaya gönüllü katılan 18 Türkçe öğretmeni oluşturmaktadır. Çalışma grubunun belirlenmesinde, olasılıklı olmayan örnekleme yöntemlerinden uygun örnekleme yöntemi (Creswell, 2013) kullanılmıştır. Araştırma, ilgili kurumdan alınan izin ile yürütülmüştür. Çalışma grubunun cinsiyet, meslek deneyimi ve yaş durumu, Tablo 1'de gösterilmiştir.

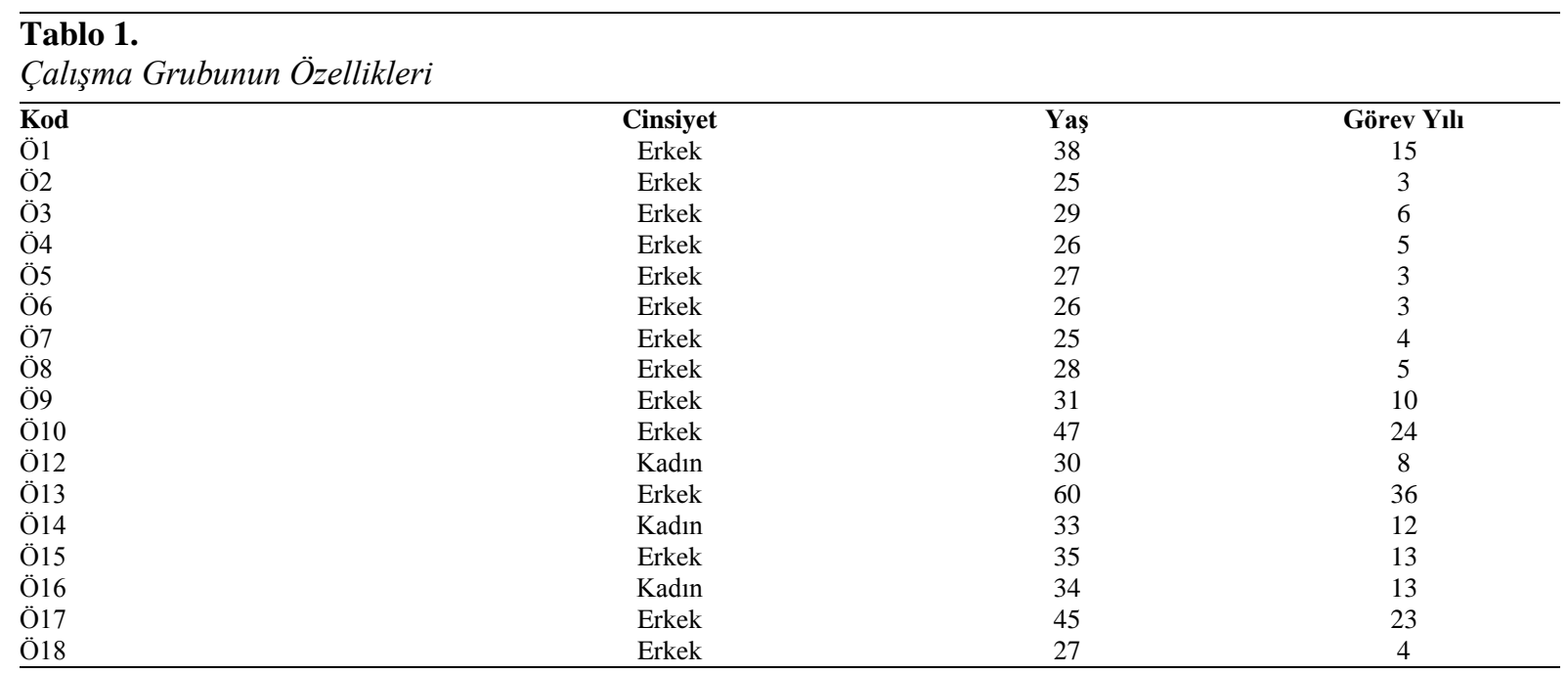




\subsection{Veri Toplama Aracı ve Verilerin Toplanması}

Araştırmanın veri toplama aracını, yarı yapılandırılmış görüşme formu oluşturmaktadır. Yarı yapılandırılmış görüşme formunda; öğretmen kılavuz kitaplarının derse hazırlık, ders işleme, ölçme ve değerlendirme süreçlerine ilişkin üç soru, öğretmen kılavuz kitaplarının kullanılmamasına yönelik ise bir soru bulunmaktadır. Yarı yapılandırılmış görüşme formundaki sorular 3 alan uzmanı ve 5 Türkçe öğretmenine gösterilmiş ve görüşleri alınarak sorulara son şekli verilmiştir. Çalışmaya katılan Türkçe öğretmenleriyle görüşülmüşs ve bu görüşmelerde çalışmanın içeriği, amacı ve niçin önemli olduğu hakkında öğretmenlere açıklamalar yapılmıştır. Öğretmenlerin araştırma konusuna yönelik merak ettiği sorulara cevaplar verilmiş ve öğretmenlere görüşlerinin önemli olduğu, alanda yaşanan sorunların belirlenmesi ve giderilmesi için görüşlerine ihtiyaç duyulduğu belirtilmiştir. Öğretmenlere, soruların cevaplarını yazılı mı yoksa sözlü mü paylaşmak istedikleri sorulmuştur. Öğretmenler, formun kendilerine bırakılması durumunda sorulara yazılı olarak cevap verebileceklerini ifade etmișlerdir. Yarı yapılandırılmış görüşme formu, öğretmenlere bırakılmış ve iki hafta süre verilmiştir. Bu sürenin ardından öğretmenlerden yarı yapılandııılmış görüşme formları alınarak çalışmanın veri toplama işlemi tamamlanmıştır.

\subsection{Verilerin Çözümlenmesi}

Yarı yapılandırılmış görüşme formu yoluyla elde edilen veriler, MAXQDA 12 nitel veri analizi programına aktarılmış ve içerik analizi tekniği kullanılarak çözümlenmiş̧ir. İçerik analizinde yapılan temel işlem, birbirine benzeyen verileri belirli kavramlar ve temalar çerçevesinde bir araya getirmek ve bunları okuyucunun anlayacağı biçimde düzenleyerek yorumlamaktır (Yıldırım ve Şimşek, 2013). Araştırmada içerik analizi türlerinden kategorisel analiz kullanılmıştır. Kategorisel analizde önce veriler kodlanmıştır. Kodlar, kelime gruplarını sınıflandırmak ya da gruplandırmak için kullanılan semboller; araş̧ırma sorularıyla ilgili olan kavramlardır (Robson, 2001). Verilerin çözümlenmesinde geçerlik ve güvenirliği sağlamak için kodlamalar iki alan uzmanı ile gerçekleştirilmiş ve kodlara ilişkin öğretmen görüşlerinden doğrudan aktarımlar yapılmıştır. Çözümlenen veriler, program aracılığıyla elde edilen görsellerle sunulmuş ve yorumlanmıştır.

\section{BULGULAR}

\subsection{Kılavuz Kitap Kullanımının Derse Hazırlık Açısından Olumlu ve Olumsuz Yönleri}

Türkçe öğretmenlerinin Türkçe dersi öğretmen kılavuz kitaplarının derse hazırlık temasına ilişkin görüşlerinden ortaya çıkan kod ağacı ve ifadelerinin kod ağacına dağılımı, Şekil l'de gösterilmiştir.

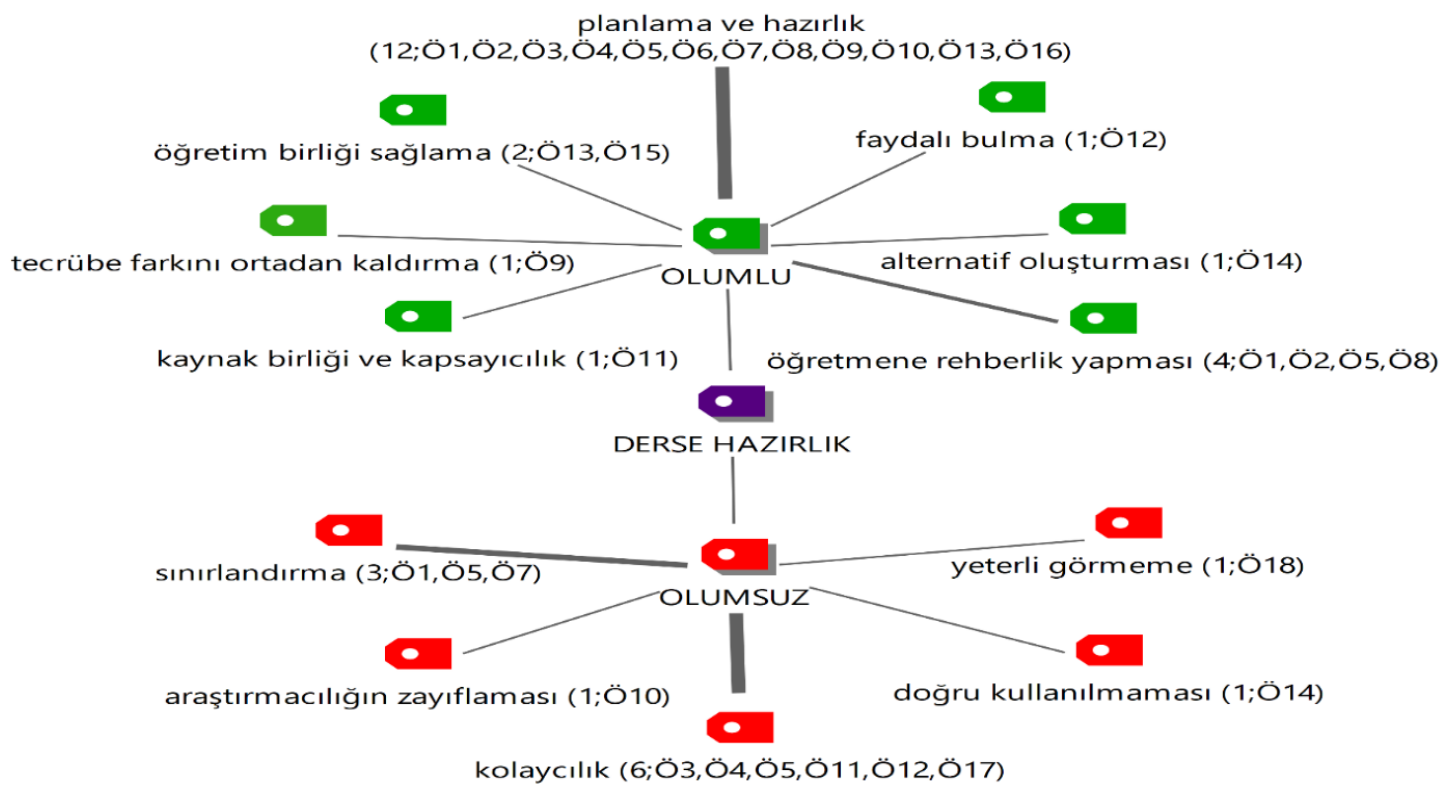

Şekil 1. Derse Hazırlık Temasına İlişkin MAX Maps Kod Birlikte Oluşma Modeli

Şekil 1 incelendiğinde; Türkçe dersi öğretmen kılavuz kitaplarının derse hazırlık temasına yönelik belirtilen öğretmen görüşlerinin olumlu ve olumsuz görüşler şeklinde ayrıldığı görülmektedir. Olumlu görüşlere ilişkin ortaya çıkan kodlar ve bu kodların sıklığı şu şekildedir: öğretmene rehberlik yapması (4), kaynak birliği ve kapsayıcılık (1), tecrübe farkını ortadan kaldırması (1), alternatif oluşturması (1), ögretim birliğini să̆lama (2), faydalı bulma (1), planlama ve hazırlı (12). Türkçe öğretmenleri, Türkçe dersi öğretmen kılavuz kitaplarının öğretmene derse hazırlık açısından en fazla planlama ve hazırlık yönünden katkısının üzerinde durmuşlardır. 
Türkçe öğretmenlerinin Türkçe dersi öğretmen kılavuz kitaplarının derse hazırlık temasına ilişkin olumlu görüş örnekleri, aşağıda sunulmuştur.

Ö9: Derse hazırlık bakımından tecrübeli öğretmenler kılavuz kitaplara çok da başvurmuyorlar ancak mesleğe yeni başlayan ögretmenler açısından eksikliği olumsuz sonuçlar doğurabilir (tecrübe farkını ortadan kaldırma).

Ö14: Olumlu yönleri olarak öğretmenlerin aklına gelmeyen önerilerin olması, alternatif oluşturması açısından çok faydalı buluyorum (alternatif oluşturması).

Ö13: Özellikle genç ögretmenler neyi nasıl ve ne zaman yapacă̆ını bilir zümreler arası birliği sağlar (öğretim birliğini sağlama).

Ö12: Derse hazırlık açısından faydalı olduğunu düşünüyorum. Normal şartlarda bir öğretmenin hazırlık aşamasında gözden kaçıracağı konuların vs. her şeyin yer alması onu faydalı yapmaktadır (faydalı bulma).

Ö11: Kaynak birliği, kapsayıcılı̆̆ ve bakanlığımızın uhdesinde olmasl yararlı (kaynak birliği ve kapsayıcılık).

Ö1: Öğretmene rehberlik yapması, ögretmen ve ögrencinin ders için yapacă̆ hazırlıklara yer vermesi, yıllık plan ve ders kitabını birlikte içermesi olumlu yönleridir (planlama ve hazırlık).

Ö6: Amacına uygun olarak kullanıldığında günlük plan oluştururken oldukça faydalı. Zamanı da oldukça ekonomik kullanma adına önemli (planlama ve hazırlık).

Ö10: Öğretmenin derse hazırlanmasında zaman açısından faydası oluyordu. Bunun için yapılacak araştırma bizim için bir vakit kaybı oluyordu. Gerektiğinde ek çalışmalar zaten yapılıyordu (planlama ve hazırlık).

Ö1: Öğretmene rehberlik yapması, ögretmen ve ögrencinin ders için yapacă̆ hazırlıklara yer vermesi, yıllık plan ve ders kitabını birlikte içermesi olumlu yönleridir (öğretmene rehberlik yapması).

Ö5: Öğretmene iyi bir rehber olur. Hangi kazanımın hangi etkinlikte kazandıracă̆l verildiğinden konunun daha iyi kavratılmasında öğretmene kolaylık să̆lar (öğretmene rehberlik yapması).

Olumsuz görüşlere ilişskin ortaya çıkan kodlar ve bu kodların sıklığg şu şekildedir: sınırlandırma, (3), yeterli görmeme (1), araştırmacılı̆̆ın zayıflaması (1), doğru kullanılmaması (1), kolaycılık (6). Türkçe öğretmenleri, Türkçe dersi öğretmen kılavuz kitaplarının öğretmene derse hazırlık açısından en fazla kolaycılık yönünden olumsuzluk oluşturduğunun üzerinde durmuşlardır. Türkçe öğretmenlerinin Türkçe dersi öğretmen kılavuz kitaplarının derse hazırlık temasına ilişkin olumsuz görüş örnekleri, aşağıda sunulmuştur.

Ö15: Açıkçası derse hazırlık olarak çok doyurucu bir etkisi olmadığı için olumsuzluk teşkil ediyor (yeterli görmeme).

Ö10: Olumsuz yönü de araştırma yanını zayıflatıyor (araştırmacılığın zayıflaması).

Ö12: Olumsuz yönlerini şöyle değerlendirmek istiyorum açıkçası kendini geliştirmek istemeyen ögretmen arkadaşların kılavuz kitaba güvenip herhangi bir hazırlık yapmaması (kolaycılık).

Ö5: Öğretmene neyi ne zaman yapacă̆ını göstermesi hazırcılı̆̆a yol açabilir. Öğretmenin planını yapmadan gitmesine neden olabilir bu da ögretmenin derse hazırlıksı gitmesine neden olur (kolaycilık).

Ö1: Olumsuz yönünün ise ögretmen ve öğrenciyi belirli bir kalıbın içine sıklştırdığı söylenebilir (sınırlandırma).

Derse hazırlık temasına yönelik olumlu ve olumsuz görüşlerden ortaya çıkan kodlara bakıldığında; olumlu görüşlerde 7 kod 22 ifade, olumsuz görüşlerde 5 kod 12 ifade ortaya çıkmıştır. Türkçe öğretmenlerinin Türkçe dersi ögretmen kılavuz kitaplarının derse hazırlık açısından olumlu yönlerinin üzerinde daha fazla durdukları görülmektedir.

\subsection{Kılavuz Kitap Kullanımının Ders İşleme Süreci Açısından Olumlu ve Olumsuz Yönleri}

Türkçe öğretmenlerinin Türkçe dersi öğretmen kılavuz kitaplarının ders işleme süreci temasına ilişkin görüşlerinden ortaya çıkan kod ağacı ve ifadelerinin kod ağacına dağılımı, Şekil 2'de gösterilmiştir. 


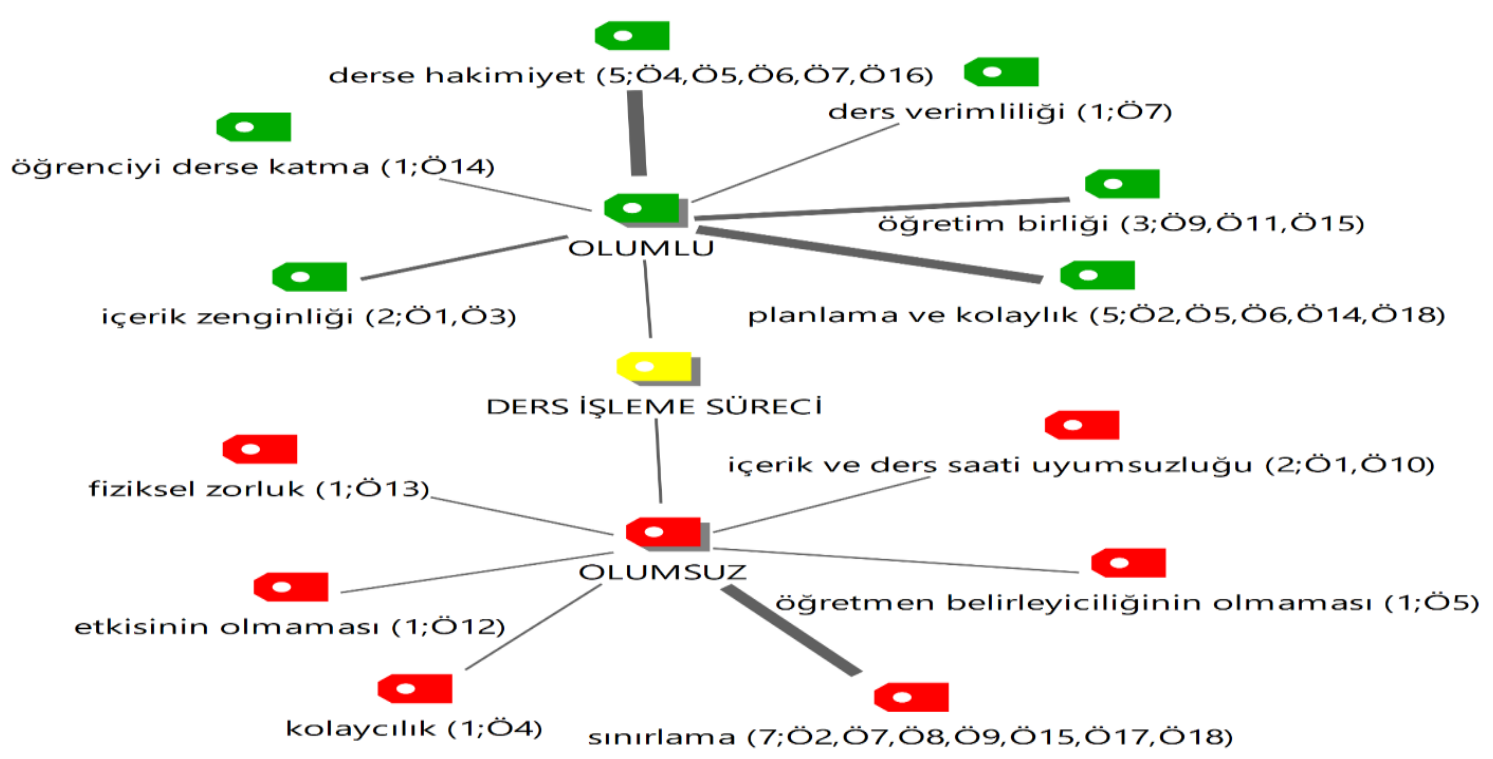

Şekil 2. Ders İ̧sleme Süreci Temasına Illişkin MAX Maps Kod Birlikte Oluşma Modeli

Şekil 2 incelendiğinde; Türkçe dersi öğretmen kılavuz kitaplarının ders işleme süreci temasına yönelik belirtilen öğretmen görüşlerinin olumlu ve olumsuz görüşler şeklinde ayrıldığı görülmektedir. Olumlu görüşlere ilişkin ortaya çıkan kodlar ve bu kodların sıklığı şu şekildedir: planlama ve kolayllk (5), içerik zenginliği (2), öğretim birliği (3), ögrrenciyi derse katma (1), ders verimliliği (1), derse hâkimiyet (5). Türkçe öğretmenleri, Türkçe dersi öğretmen kılavuz kitaplarının ders işleme süreci açısından en fazla derse hâkimiyet, planlama ve kolaylı yönlerinden katkılarının olduğunun üzerinde durmuşlardır. Türkçe öğretmenlerinin Türkçe dersi öğretmen kılavuz kitaplarının ders işleme süreci temasına ilişkin olumlu görüş̧örnekleri, aşağıda sunulmuştur.

Ö14: Ders esnasında planlamayı sağlar ve yine öğretmenin işini kolaylaşttrır ve öğrenciyi aktif olarak derse katma açısından olumlu buluyorum (derse katılma).

Ö9: Öğrencilerin farklı ögrenme ortamlarında olmasına răgmen benzer öğrenme süreçleri yaşamaları bakımından ise olumlu buluyorum (öğretim birliği).

Ö7: Öğretmenin dersi daha etkili işlemesini sağlar (ders verimliliği).

Ö4: Ders işleme sürecinin daha etkili olmasını sağllyor. Öğretmenin konu üzerindeki hâkimiyetini artırıyor (derse hâkimiyet).

Ö16: Kllavuz kitap olmaylnca öğrenciyi takip edemiyoruz. Etkinliklerin yeri zamanı ve sirastyla ilgili ders sirasında kopukluk yaşlyoruz öğrenciden kitap istemek zorunda kalyyoruz (derse hâkimiyet).

Ö2: Ders işleme sürecinde bir yol haritası çiziyordu. Öğretmenin ders işleme plânına bir omurga olușturuyordu (planlama ve kolaylik).

Ö5: Derste neyi ne zaman yapmalıyım karmaşasının yaşanmasinı engeller. Sorulacak soruların ve yapılacak etkinliklerin kazanımlarla verilmesi ders tıkanıklı̆ıının yaşanmasını engeller (planlama ve kolaylık).

Ö1: Öğretmenlere farkl etkinliklerle konunun kavranmasına imkân vermekte ve dersin içeriğini zenginleş̧tirmektedir (içerik zenginliği).

Olumsuz görüşlere ilişkin ortaya çıkan kodlar ve bu kodların sıklı̆̆ şu şekildedir: fiziksel zorluk (1), etkisinin olmaması (1), kolaycllık (1), içerik ve ders saati uyumsuzluğu (2), öğretmen belirleyiciliğinin olmaması (1), sinırlama (7). Türkçe öğretmenleri, Türkçe dersi öğretmen kılavuz kitaplarının ders işleme süreci açısından en fazla sınırlama yönünden olumsuzluk oluşturduğunun üzerinde durmuşlardır. Türkçe öğretmenlerinin Türkçe dersi öğretmen kılavuz kitaplarının derse hazırlık temasına ilişkin olumlu görüş örnekleri, aşağıda sunulmuştur.

Ö13: Kitaplar çok kalın ve boyutları da elde taşımaya uygun değil Çok daha ince ve küçük boy olmalı kılavuz kitaplar (fiziksel zorluk).

Ö12: Ders işleme sürecinde herhangi bir etkisinin olmadı̆̆ını düşünüyorum (etkisinin olmaması).

Ö5: Sürekli bir şeye bağımlı olma öğretmenin ders işleme sürecini kendine göre ayarlayamamasına neden olur. İşlenen konu farklı bir noktaya geldiğinde ne yapmallyım sorusunu akla getirebilir (öğretmen belirleyiciliğinin olmamasi).

Ö4: Olumsuz yani ise bazı durumlarda öğretmen kılavuz kitaba aşırı bağımlı kallyor. Bu da öğretim sürecinin doğal aklşına olumsuz yansiyor (kolaycillk). 
Ö8: Kılavuz kitaplar öğretmeni konuyla ilgili sınırlamaktadır. Kazanımların öğrenciye aktarılmasında pek bir etkisi yok. Konuyla ilgili kitabın dışında farklı dokümanlar ve etkinlikler bularak dersi işlemeyi tercih ediyorum çoğunlukla (sınırlama).

Ö9: Öğretmeni belirli bir kalıp içine sokması ve öğretmenin yaratıcılı̆̆ını azaltması bakımından olumsuz (sinirlama).

Ö18: Ders işleniş sürecinde sınırlayıcı bir etki yaptığı için olumsuz durumlar doğurabiliyor (sınırlama).

Ö10: Ders işlenişi açısından bazen yapılan planlama ile verilen süre arasında bir çelişki vardı. Kitaptaki planlama ve etkinlikler verilen sürede tamamlanamıyordu (içerik ve ders saati uyumsuzluğu).

Ders işleme süreci temasına yönelik olumlu ve olumsuz görüşlerden ortaya çıkan kodlara bakıldığında; olumlu görüşlerde 6 kod 17 ifade, olumsuz görüşlerde 6 kod 13 ifade ortaya çıkmıştır. Türkçe öğretmenlerinin Türkçe dersi öğretmen kılavuz kitaplarının ders işleme süreci açısından olumlu yönlerinin üzerinde görüş olarak daha fazla durdukları görülmektedir.

\subsection{Kılavuz Kitap Kullanımının Ölçme ve Değerlendirme Açısından Olumlu ve Olumsuz Yönleri}

Türkçe öğretmenlerinin Türkçe dersi öğretmen kılavuz kitaplarının ölçme ve değerlendirme temasına ilişkin görüşlerinden ortaya kod ağacı ve ifadelerinin kod ağacına dağılımı, Şekil 3'te gösterilmiştir.

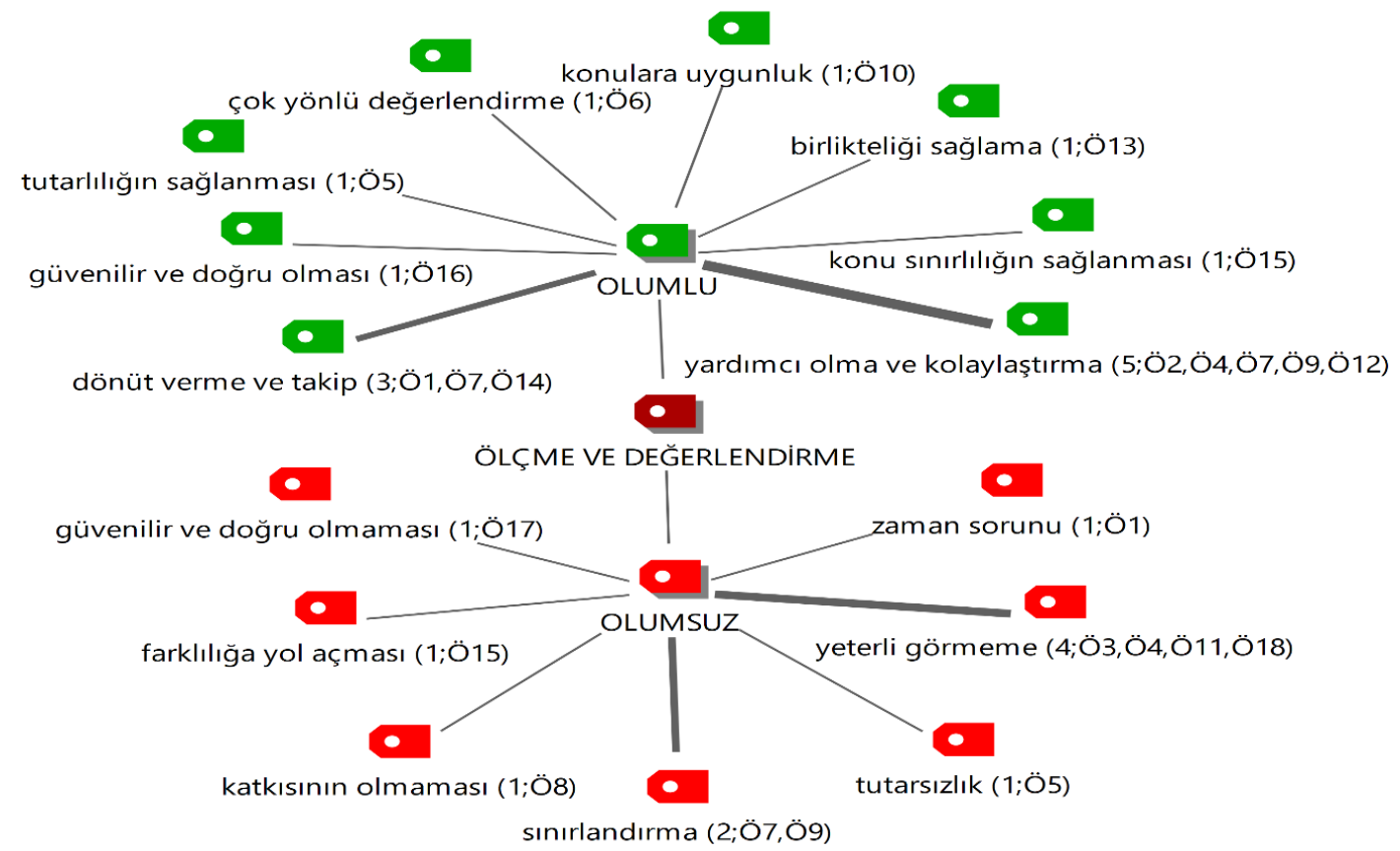

Şekil 3. Ölçme ve Değerlendirme Temasına İlişkin MAX Maps Kod Birlikte Oluşma Modeli

Şekil 3 incelendiğinde; Türkçe dersi öğretmen kılavuz kitaplarının ölçme ve değerlendirme temasına yönelik belirtilen öğretmen görüşlerinin olumlu ve olumsuz görüşler şeklinde ayrıldığı görülmektedir. Olumlu görüşlere ilişkin ortaya çıkan kodlar ve bu kodların sıklığı şu şekildedir: dönüt verme ve takip (3), güvenilir ve doğru olması (1), tutarlılı̆̆ın să̆lanması (1), çok yönlü de ğerlendirme (1), konulara uygunluk (1), birlikteliği să̆lama (1), konu sınırlılı̆̆ının sağlanması (1), yardımcı olma ve kolaylaştırma (5). Türkçe öğretmenleri, Türkçe dersi öğretmen kılavuz kitaplarının ölçme ve değerlendirme açısından en fazla yardımcı olma ve kolaylaştırma, dönüt verme ve takip yönlerinden katkılarının olduğunun üzerinde durmuşlardır. Türkçe öğretmenlerinin Türkçe dersi öğretmen kılavuz kitaplarının ölçme ve değerlendirme temasına ilişkin olumlu görüş örnekleri, aşağıda sunulmuştur.

Ö1: Yapılan etkinliklerde geri dönütler sayesinde öğrencilerin gelişim düzeyleri yakından takip edilmekteydi (dönüt verme ve takip).

Ö2: Öğrencilerin temel dil becerilerindeki yeterlilik ölçümünde ögretmene yardımcı oluyordu (yardımcı olma ve kolaylaştırma).

Ö3: Kılavuz kitaplar ögretmenlerin ölçme değerlendirme yapmasını kolaylaştırıyor (yardımcı olma ve kolaylaştırma).

Ö5: Yapılacak olan değerlendirmenin kılavuz kitapta verilen kazanımlarla örtüşmesini să̆lar. Bu da işlenen ile istenen arasında tutarlılık olmasını sağlar (tutarlılığın sağlanması).

Ö6: Alternatif ölçme araçlarının da kullanılmasına olanak sağlayan bir kılavuz kitap çok yönlü bir değerlendirmeye imkân să̆lar (çok yönlü değerlendirme). 
Ö10: Ölçme değerlendirme konulara uygundu (konulara uygunluk).

Ö13: Kişiler arası birliktelik sağladığı için olumludur (birlikteliği sağlama).

Ö16: Bu konuda kilavuz kitapta verilen ölçme değerlendirme testleri bizi daha güvenilir ve doğru sonuçlara ulaştırtyor (güvenilir ve doğru olması).

Olumsuz görüşlere ilişkin ortaya çıkan kodlar ve bu kodların sıklığ şu şekildedir: güvenilir ve doğru olmaması (1), zaman sorunu (1), farklllığa yol açması (1), katkısının olmaması (1), tutarsızlık (1), sinırlandırma (2), yeterli görmeme (4). Türkçe öğretmenleri, Türkçe dersi öğretmen kılavuz kitaplarının ölçme ve değerlendirme açısından en fazla yeterli olmaması yönünden olumsuzluk oluşturduğunun üzerinde durmuşlardır. Türkçe öğretmenlerinin Türkçe dersi öğretmen kılavuz kitaplarının ölçme ve değerlendirme temasına ilişkin olumlu görüş örnekleri, aşağıda sunulmuştur.

Ö1: Müfredatın yetiştirilememesi en büyük slkıntıydı (zaman sorunu).

Ö3: Kılavuz kitapların ölçme ve değerlendirme açısından yetersiz buluyorum (yeterli görmeme).

Ö11: Ölçülecek kazanımın kaynak kitap paralelinde olması tek başına yeterli olmayabilir (yeterli görmeme).

Ö5: Kılavuz kitapta eksik bırakılan veya verilmeyen kazanımın ölçme değerlendirmede sorulması ögrenci açısından karmaşa yaşamasına neden olabilir (tutarsızlık).

Ö9: Ancak neredeyse her şeyin hazır olmast öğretmenin ders saati dışında öğrenciler için emek vermesinin önüne geçiyor (sinırlandırma).

Ö8: Kılavuz kitaplarda ögrrencileri araştırmaya, günlük yaşamda karşılaşılan çeşitli sorunlara çözüm üretmeye yöneltecek ödev, proje ve benzeri örnek çalışmalara yer verildiği düşünülür fakat ben kalavuz kitapların ölçme değerlendirme süreçlerinde yeterince katkıda bulunduğunu düşünmüyorum (katkısının olmaması).

Ölçme ve değerlendirme temasına yönelik olumlu ve olumsuz görüşlerden ortaya çıkan kodlara bakıldığında; olumlu görüşlerde 8 kod 14 ifade, olumsuz görüşlerde 7 kod 11 ifade ortaya çıkmıştır. Türkçe öğretmenlerinin Türkçe dersi öğretmen kılavuz kitaplarının ölçme ve değerlendirme açısından olumlu yönlerinin üzerinde görüş olarak daha fazla durdukları görülmektedir.

\subsection{Kılavuz Kitap Kullanılmamasının Derse Hazırlık, Ders İşleme Süreci, Ölçme ve Değerlendirme Açısından Olumlu ve Olumsuz Yönleri}

Türkçe öğretmenlerinin Türkçe dersi öğretmen kılavuz kitaplarının kullanılmaması durumuna ilişkin derse hazırlık, ders işleme süreci, ölçme ve değerlendirme temalarına yönelik görüşlerinden ortaya çıkan kod ağacı ve ifadelerinin kod ağacına dağılımı, Şekil 4 'te gösterilmiştir.

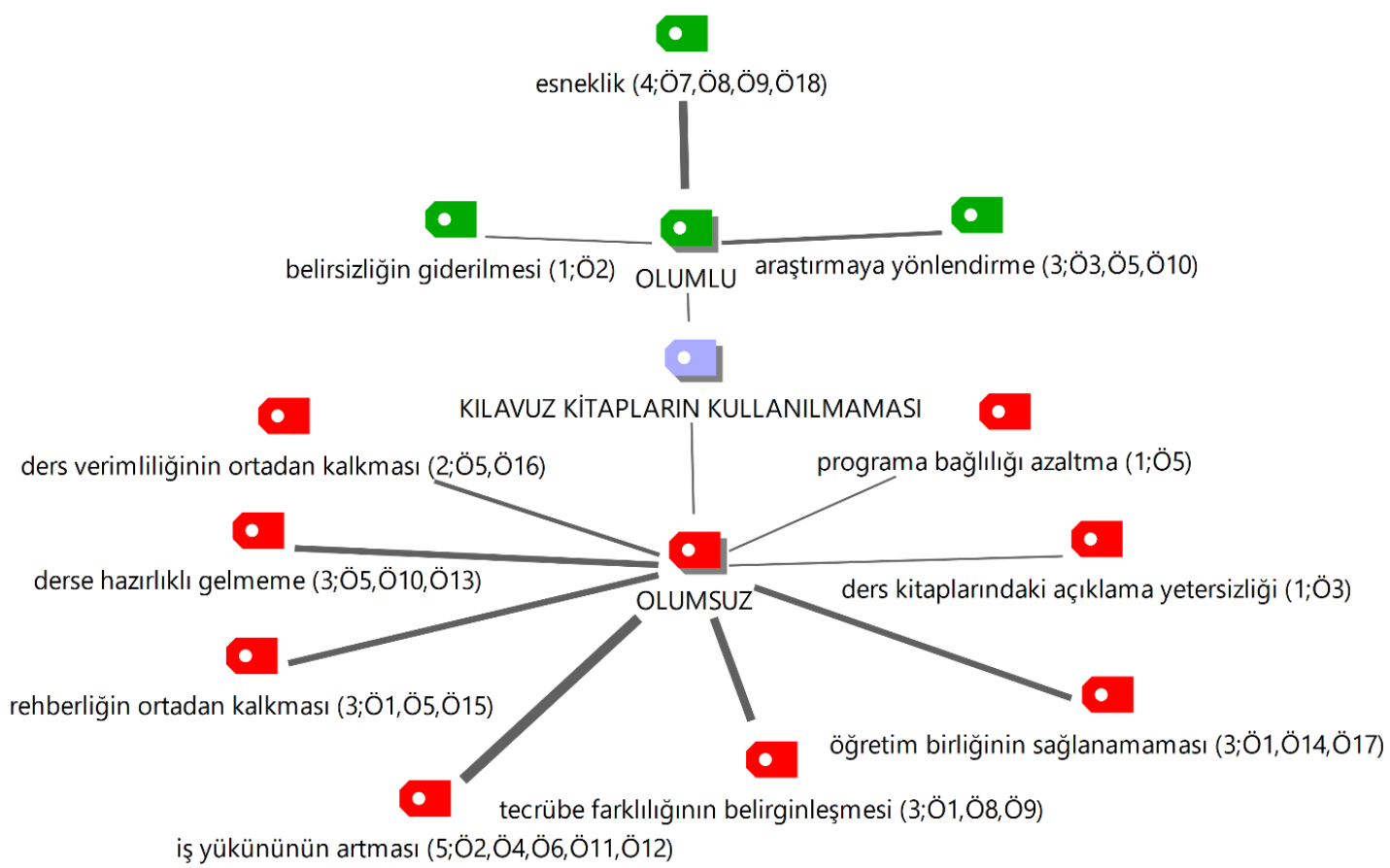

Şekil 4. Kılavuz Kitapların Kullanılmamasına İlişkin MAX Maps Kod Birlikte Oluşma Modeli

Şekil 4 incelendiğinde; Türkçe dersi öğretmen kılavuz kitaplarının kullanılmamasına yönelik belirtilen öğretmen görüşlerinin olumlu ve olumsuz görüşler şeklinde ayrıldığı görülmektedir. Olumlu görüşlere ilişkin ortaya çıkan kodlar ve bu kodların sıklığı şu şekildedir: belirsizliğin giderilmesi (1), araştırmaya yönlendirme (3), esneklik (4). 
Türkçe öğretmenleri, Türkçe dersi öğretmen kılavuz kitaplarının kullanılmamasının en fazla esneklik ve araştırmaya yönlendirme yönlerinden katkılarının olduğunun üzerinde durmuşlardır. Türkçe öğretmenlerinin Türkçe dersi öğretmen kılavuz kitaplarının kullanılmamasına ilişkin olumlu görüş örnekleri, aşağıda sunulmuştur.

Ö2: Olumsuz yönü ise bunların tam anlamıyla bu süreçleri karşılayamıyor oluşuydu. Bazı metinlerde daha açık ve net ifadelerin kullanılmaması sorun teşkil ediyordu (belirsizliğin giderilmesi).

Ö3: Kılavuz kitapların kullanılmaması derse hazırlık açısından olumlu bir etki yapmaktadır. Derse hazırlanıp gidiyorum, işleyeceğim konuya önceden göz atıyorum, etkinliklerine bakıyorum (araştırmaya yönlendirme).

Ö10: Ayrıca kılavuz kitapların olmaması ögretmeni araştırmaya yöneltiyor (araştırmaya yönlendirme).

Ö18: Kitapların kullanılmaması ders öncesi ve sonrası süreçte ögretmene daha etkin bir imkân sağllyor. Çünkü ögretmenler ihtiyaç ve durumlara göre kendi yöntemlerini kullanabiliyorlar (esneklik).

Ö8: Öğretmenler daha rahat hareket edip kendini sınırlamadan konunun özellikle üzerinde durulması gereken kısımlarına ă̆ırlık verebilir. Öğretmenleri sınırlandırmayacă̆ için daha geniş ve kapsamlı bir öğretim süreci olur (esneklik).

Olumsuz görüşlere ilişkin ortaya çıkan kodlar ve bu kodların sıklığı şu şekildedir: programa bağlılı̆̆ı azaltma (1), ders kitaplarındaki açıklama yetersizliği (1), ders verimliliğinin ortadan kalkması (2), derse hazırlıklı gelmeme (3), rehberliğin ortadan kalkması (3), öğretim birliğinin sağlanamaması (3), tecrübe farklılı̆̆ının belirginleşmesi (3), iş yükünün artması (5). Türkçe öğretmenleri, Türkçe dersi öğretmen kılavuz kitaplarının kullanılmamasının en fazla iş yükünün artması, ögretim birliğinin sağlanamaması, rehberliğin ortadan kalkması ve derse hazırlıklı gelmeme yönlerinden olumsuzluk oluşturduğunun üzerinde durmuşlardır. Türkçe öğretmenlerinin Türkçe dersi öğretmen kılavuz kitaplarının kullanılmamasına ilişkin olumsuz görüş örnekleri, aşağıda sunulmuştur.

Ö5: Kazanımlara bağlı olmadan daha farklı şekilde kazanım vermek ölçme değerlendirme açısından sıkıntılara yol açabilir (programa bağlılı̆̆ azaltma).

Ö16: Kullanılmadı ̆̆ zaman öğrenci ve ögretmen arasında kopukluk yaşanıyor. Öğrenciden kitap isteyip öncesinde planlamamı gerekiyor ve bu durum sureci olumsuz etkiliyor (ders verimliliğinin ortadan kalkması).

Ö10: Fakat derslere planlı ve hazırlıkl gelmiyorsanız kılavuz kitap olmaması olumsuzluktur (derse hazırlıklı gelmeme).

Ö3: Bazl etkinliklerde ne istendiği çok iyi açıklanmadı̆̆g için cevaplandırmalarda ve öğrencileri yönlendirmede zorluk çekiyorum (ders kitaplarındaki açıklama yetersizliği).

Ö2: Belirtilen süreçlerde her yönüyle öğretmenin iş yükünü azaltıyor ve yardımcı oluyordu (iş yükünün artmas1). Ö6: Kullanılmaz ise ögretmenin iş yükü artar ve ögretmende bitkinlik oluşturabilir (iş yükünün artması).

Ö1: Tüm ĕgitim öğretim sürecinde ögretmene yol gösteriyordu (rehberliğin ortadan kalkması).

Ö8: Mesleğe yeni başlayan ögretmenler, alanının dışında derse giren öğretmenler ve alanının dlşında bir branşta ücretli ögretmenlik yapan kişiler için ise aynı durum geçerli değildir çünkü bu kişiler için kılavuz kitap olmazsa olmaz bir yardımcı kaynaktır (tecrübe farklılığının belirginleşmesi).

Ö9: Olumsuz olabilecek asıl nokta da bu yeterliliklere sahip olamayan ögretmenler bakımından ortaya çıkabilecektir (tecrübe farklılığının belirginleşmesi).

Ö14: Ĕ̈itim ögretim birliğini ortadan kaldırdı̆̆ını düşündüğ̈̈m için kılavuz kitabın kullanılmamasını doğru bulmuyorum. Sadece ögretmenin yaratıcılı̆̆ına bırakmak yerine kllavuz kitaplarla öğretmene de aslında yeni fikirler verilmiş olur (öğretim birliğinin sağlanamaması).

Ö1: Ülkede uygulama birlikteliği olmasını sağlayan en önemli fırsatın kaybedildiği görülüyor (öğretim birliğinin sağlanamamas1).

Öğretmen kılavuz kitabı kullanılmaması temasına yönelik olumlu ve olumsuz görüşlerden ortaya çıkan kodlara bakıldığında; olumlu görüşlerde 3 kod 8 ifade, olumsuz görüşlerde 8 kod 21 ifade ortaya çıkmıştır. Türkçe öğretmenlerinin Türkçe dersi öğretmen kılavuz kitaplarının kullanılmamasının ortaya çıkardığı olumsuzluklar üzerinde daha fazla durdukları görülmektedir.

Türkçe öğretmenlerinin Türkçe dersi öğretmen kılavuz kitaplarının kullanılmasına ve kullanılmamasına yönelik görüşlerinden hareketle ortaya çıkan tema ve bu temaların kodlarına dağılımları, Şekil 5 'te gösterilmiştir. 


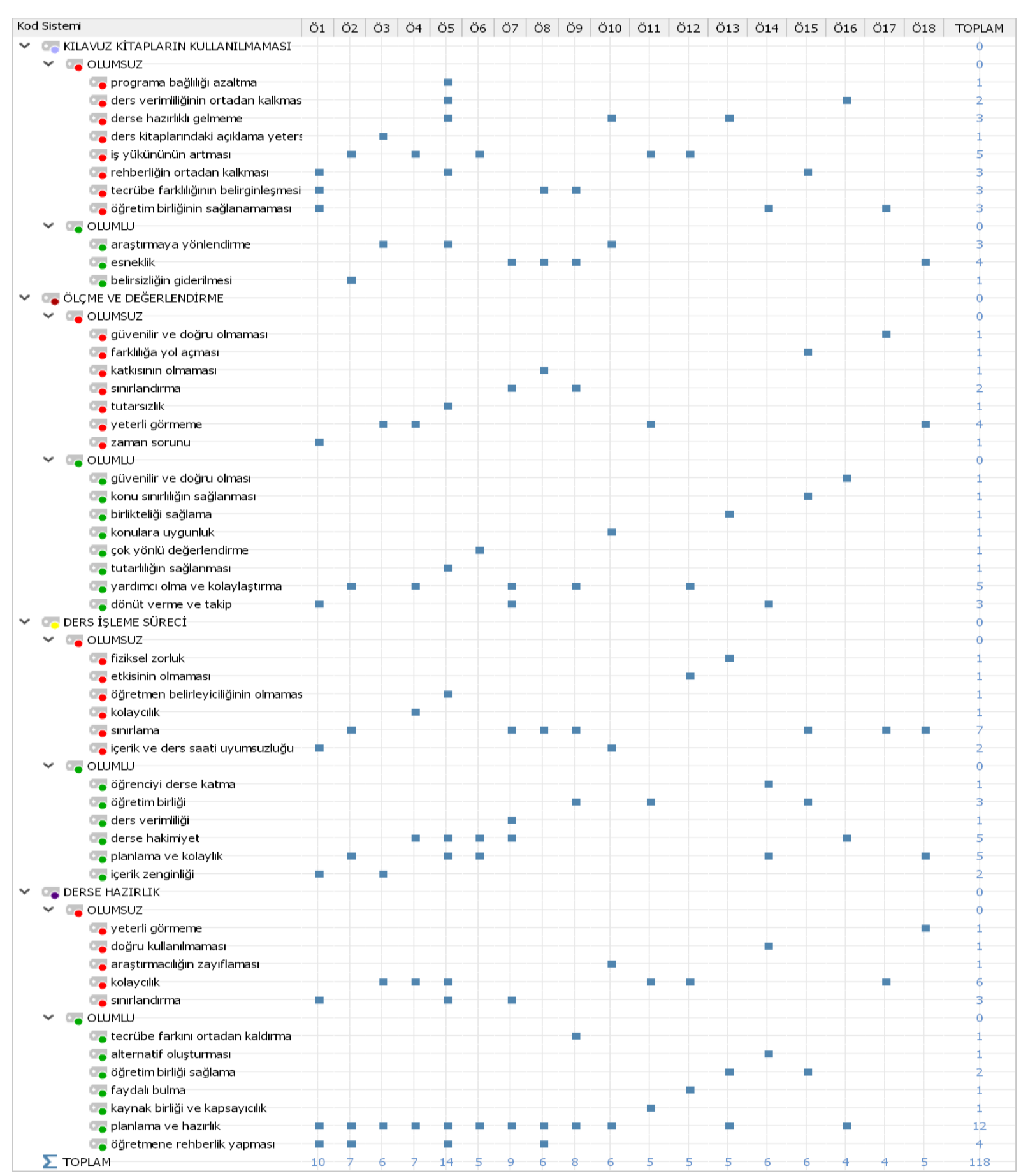

\section{Şekil 5. Öğretmenlerin Tema ve Kodlara Yönelik Dă̆llımları}

Şekil 5 incelendiğinde, kılavuz kitapların derse hazırlık açısından en fazla planlama ve hazırlık yönlüyle öğretmenlere katkısının olduğu, kolaycılık oluşturması nedeniyle olumsuzluk oluşturduğu; ders işleme süreci açısından en fazla derse hakimiyet, planlama ve kolaylık yönleriyle öğretmenlere katkısının olduğu, öğretmenleri sınırlaması nedeniyle olumsuzluk oluşturduğu; ölçme ve değerlendirme açısından en fazla öğretmenlere yardımcı olması ve öğretmenlerin işini kolaylaştırması yönleriyle katkısının olduğu, öğretmenler tarafından yeterli görülmemesi nedeniyle olumsuzluk oluşturduğu görülmektedir.

\section{SONUÇ VE TARTIŞMA}

Araştırma, uygulamadan kaldırılan Türkçe dersi öğretmen kılavuz kitaplarının kullanılma durumunun derse hazırlık, ders işleme süreci, ölçme ve değerlendirme açılarından olumlu ve olumsuz yönleri ile kılavuz kitapların kullanılmaması durumunun olumlu ve olumsuz yönlerinin belirlenmesi amacıyla gerçekleştirilmiştir. Türkçe öğretmenlerinin Türkçe dersi öğretmen kılavuz kitaplarının kullanımının derse hazırlık, ders işleme süreci, ölçme 
ve değerlendirme açılarından ve kılavuz kitapların kullanılmaması durumunun ortaya çıkardığı olumlu ve olumsuz durumlara yönelik görüşlerinden ortaya çıkan sonuçlar, aşağıda sunulmuştur.

Türkçe öğretmenleri, Türkçe dersi öğretmen kılavuz kitaplarının derse hazırlık açısından öğretmenlere en fazla dersi planlama ve ders hazırlığı yapma yönünden yararlı olduğunu ancak kılavuz kitapların öğretmenleri kolaycılığa alıştırması yönüyle olumsuzluk oluşturduğunu belirtmişlerdir. Türkçe öğretmenleri, Türkçe dersi öğretmen kılavuz kitaplarının derse hazırlık açısından olumlu yönlerinin üzerinde daha fazla görüş belirtmişlerdir.

Türkçe öğretmenleri, Türkçe dersi öğretmen kılavuz kitaplarının ders işleme süreci açısından öğretmenlere en fazla derse hâkimiyetin sağlanması, planlama yapılabilmesi ve kolaylık oluşturması yönlerinden katkılarının olduğunu ancak kılavuz kitapların öğretmenleri sınırlaması yönüyle olumsuzluk oluşturduğunu belirtmişlerdir. Türkçe öğretmenleri, kılavuz kitapların ders işleme süreci açısından olumlu yönlerinin üzerinde daha fazla görüş belirtmişlerdir.

Türkçe öğretmenleri, Türkçe dersi öğretmen kılavuz kitaplarının ölçme ve değerlendirme açısından öğretmenlere en fazla yardımcı olması ve öğretmenin işini kolaylaştırması, dönüt verme ve takip yapılabilmesi yönlerinden katkılarının olduğunu ancak kılavuz kitapların öğretmenler tarafından yeterli görülmemesinin olumsuzluk oluşturduğunu belirtmişlerdir. Türkçe öğretmenleri, kılavuz kitaplarının ölçme ve değerlendirme açısından olumlu yönlerinin üzerinde daha fazla görüş belirtmiş̧lerdir.

Türkçe öğretmenleri, Türkçe dersi öğretmen kılavuz kitaplarının kullanılmamasının öğretmenlere en fazla esneklik tanıma ve araştırmaya yönlendirme açılarından katkılarının olduğunu ancak öğretmenlerin iş yükünün artması, öğretim birliğinin sağlanamaması, öğretmen rehberliğinin ortadan kalkması ve öğretmenin derse hazırlıklı gelmemesi yönlerinden olumsuzluk oluşturduğunu belirtmişlerdir. Türkçe öğretmenleri, kılavuz kitapların kullanılmamasının ortaya çıkardığı olumsuzluklar üzerinde daha fazla görüş belirtmişlerdir.

Bu sonuçlara genel olarak bakıldığında, ortaokul Türkçe dersi öğretmen kılavuz kitaplarının kullanılması görüşü ön plana çıkmaktadır. Türkçe öğretmenleri, kılavuz kitapların olumsuz yönlerini de belirtmişler ancak olumlu yönleri üzerinde daha fazla durmuşlardır.

Alkış-Küçükaydın ve İşcan (2017), ilköğretim 3. sınıf Türkçe ders kitapları ve öğretmen kılavuz kitabının yapılandırmacı öğrenme yaklaşımına uygunluk düzeyi konulu çalışmasında, 3. sınıf Türkçe dersi öğretmen kılavuz kitaplarının araştırmaya sevk edici nitelikte olmadığ 1 , ölçme değerlendirmede yetersiz kaldığı, yönergeler sunmada başarısız olduğu ve yöntem teknikler konusunda hatalarının bulunduğu sonuçlarına ulaşmışlardır. Araştırmanın kılavuz kitapların öğretmenleri araştırmaya sevk edici nitelikte olmadığı sonucu ile bu araştırmanın kılavuz kitapların öğretmeni kolaycılığa alıştırması, araştırmanın kılavuz kitapların ölçme ve değerlendirmede yetersiz kalması ile bu araştırmanın kılavuz kitapların ölçme ve değerlendirmede yeterli görülmemesi, araştırmanın kılavuz kitapların yönergeler sunmada başarısız olması ile bu araştırmanın derse hazırlık noktasında kılavuz kitapların yeterli görülmemesi sonucu benzerlik göstermektedir.

Bağcı (2010), ilköğretim Türkçe Dersi 6. Sınıf Öğretmen Kılavuz Kitabı'nın Türkçe Dersi Öğretim Programı dil bilgisi alanı açısından incelenmesi konulu çalışmasında, İlköğretim 6. Sınıf Türkçe Dersi Öğretmen Kılavuz Kitabı'nın Türkçe Dersi Öğretim Programı dil bilgisi alanıyla uyumsuz olduğu sonucuna ulaşmıştır. Bu araştırmada dil bilgisine ilişkin herhangi bir bulgu ortaya çıkmamıştır. Araştırmada ortaya çıkan içerik uyumsuzluğu ile Bağcı'nın (2010) araştırmasında dil bilgisi ile kılavuz kitabın uyumlu olmaması sonuçları benzer olarak değerlendirilebilir.

Göçer ve Aktürk (2015), ilk ve ortaokul öğretmenlerinin öğretmen kılavuz kitabına yönelik algıları konulu çalışmasında, öğretmenlerin çoğunluğunun kılavuz kitabı yol gösterici ve yardımcı olarak gördükleri, bazı öğretmenlerin kılavuz kitabın öğretmenleri dar bir kalıp içine hapsettiğini, bazı öğretmenlerin ise yararlı yönlerinin olduğunu düşünmekle birlikte öğretmenlerin yaratıcılığını sınırladığını düşündükleri sonuçlarına ulaşmışlardır. Araştırmada öğretmenlerin kılavuz kitapları yol gösterici ve yardımcı olarak görmeleri sonucu ile bu araştırmanın kılavuz kitapların derse hazırlık yönüyle öğretmene rehberlik yapması, planlamada ve hazırlıkta yardımcı olması, ders işleme süreci yönüyle öğretmene planlama ve kolaylık sağlaması sonuçları benzerlik göstermektedir. Araştırmanın kılavuz kitapların öğretmenlerin yaratıcılığını sınırlandırması sonucu ile bu araştırmanın kılavuz kitapların derse hazırlık yönüyle öğretmeni sınırlandırması ve öğretmenlerin araştırmacılığının zayıflaması, ders işleme yönüyle öğretmenleri sınırlaması sonuçları benzerlik göstermektedir.

Göçer ve Sayın (2014), 6, 7 ve 8. sınıf Türkçe kılavuz kitaplarındaki metinlerin dil bilgisi öğretimindeki yeterliliği ve kullanım durumları" konulu çalışmasında, kılavuz kitaplarındaki metinlerin dil bilgisi konuları ile uyumlu olmadığ sonucuna ulaşmıştır. Araştırmanın kılavuz kitaplardaki metinlerin dil bilgisi konuları ile uyumlu olmaması sonucu ile bu araştırmada ortaya çıkan kılavuz kitaplardaki içerik uyumsuzluğu sonucu, benzer olarak değerlendirilebilir. 
Yaylı ve Solak (2014), ortaokul Türkçe ders kitaplarında ve öğretmen kılavuz kitaplarında yazma etkinlikleri konulu çalışmasında, öğretmenlerin genel anlamda etkinlikleri yeterli bulduğu, sınıfların kalabalık olmasının ve zaman yetersizliğinin eğitim sürecini olumsuz etkilediği ve değerlendirme konusunda gelişimin gerekli olduğu sonuçlarına ulaşmışlardır. Araştırmanın genel anlamda etkinliklerin yeterli bulunması sonucu ile bu araştırmanın ders işleme süreci açısından kılavuz kitapların içerik zenginliğine sahip olması sonucu benzer olarak değerlendirilebilir.

Araştırma ile elde edilen öğretmen görüşlerinden hareketle Türkçe dersi öğretmen kılavuz kitaplarının kullanımdan kaldırılması yerine kılavuz kitap kullanımının ortaya çıkardığı olumsuzlukların giderilmesi ve kitapların güncellenerek kullanılması önerilmektedir. 


\section{KAYNAKÇA}

Alkış-Küçükaydın, M. ve İşcan, A. (2017). İlköğretim 3. sınıf Türkçe ders kitapları ve öğretmen kılavuz kitabının yapılandırmacı öğrenme yaklaşımına uygunluk düzeyi. Ana Dili Eğitimi Dergisi, 5(1), 1-13.

Ayvacı, H. Ş. ve Er-Nas, S. (2009). Öğretmen Kılavuz Kitaplarının yapılandırmacı kurama göre öğretmen görüşlerine dayalı olarak değerlendirilmesi, Necatibey Eğitim Fakültesi Elektronik Fen ve Matematik Eğitim Dergisi, 3(2), 212-225.

Bağcı, A. B. (2010). İlköğretim Türkçe Dersi 6. sınıf ögretmen kılavuz kitabının Türkçe dersi öğretim programı dil bilgisi alanı açısından incelenmesi. (Yayımlanmamış yüksek lisans tezi), Afyon Kocatepe Üniversitesi Sosyal Bilimler Enstitüsü, Afyonkarahisar.

Creswell, J. W. (2013). Research design: qualitative, quantitative, and mixed methods approaches. New York: Sage.

Göçer, A. (2011). İlköğretim ikinci kademe Türkçe Öğretmen Kılavuz Kitaplarının işlevselliğinin belirlenmesi. Uluslararası Sosyal Araştırmalar Dergisi, 4(16), 154- 164.

Göçer, A. ve Aktürk, Y. (2015). İlk ve ortaokul öğretmenlerinin öğretmen kılavuz kitabına yönelik algıları: metafor analizi. Ulusararası Türk Ë̆itim Bilimleri Dergisi, 4, 186-199.

Göçer, A. ve Sayın, H. (2014). 6, 7 ve 8. Sınıf Türkçe Kılavuz Kitaplarındaki metinlerin dil bilgisi öğretimindeki yeterliliği ve kullanım durumlarının incelenmesi. Journal of European Education, 4(2), 11-28.

Kurudayığlu, M. ve Örge-Yaşar, F. (2014). 6. sınıf Türkçe dersi öğretmen kılavuz kitaplarındaki dinleme metinlerinin dinleme yöntem ve teknikleri açısından incelenmesi. Ana Dili Eğitimi Dergisi, 2(2), 1-14.

MEB (2005). Millî Eğitim Bakanlığı Eğitim ve Öğretim Çalışmalarının Plânlı Yürütülmesine İlişkin Yönerge. Tebliğler Dergisi, 68(2575), 1-72. http://mevzuat.meb.gov.tr/dosyalar/284.pdf adresinden 24.03.2019 tarihinde erişilmiştir.

MEB (2015). Ortaokul Türkçe 6. sınıfögrretmen kılavuz kitabı. Ankara: MEB Yayınları.

Merriam, S. B. (2013). Nitel araştırma: Desen ve uygulama için bir rehber (3. Baskıdan Çeviri). Çeviri Editörü: S. Turan. Ankara: Nobel Yayın Dağıtım.

Patton, M. Q. (2002). Qualitative research \& evaluation methods (3.ed.). Hershey, PA: Sage.

Resmî Gazete (2012). Millî Eğitim Bakanlığı Ders Kitapları ve Eğitim Araçları Yönetmeliği. Sayı: 28409. 24.03.2019 tarihinde http://www.resmigazete.gov.tr/eskiler/2012/09/20120912-2.htm adresinden alınmıştır.

Robson, C. (2001). Real world research. Oxford: Blackwell Publishers.

Temizyürek, F. ve Balcı, A. (2015). Cumhuriyet dönemi ilköğretim okulları Türkçe öğretim programları. (2. Baskl). Ankara: Nobel Yayıncilık.

Yaylı, D. ve Solak, M. (2014). Ortaokul Türkçe ders kitaplarında ve öğretmen kılavuz kitaplarında yer alan yazma etkinliklerine dair öğretmen görüşleri. Turkish Studies International Periodical For The Languages, Literature and History of Turkish or Turkic, 9(6), 1139-1151.

Yıldırım, A. ve Şimşek, H. (2013). Sosyal bilimlerde nitel araştırma yöntemleri (9. Baskı). Ankara: Seçkin Yayıncilık. 


\section{EXTENDED ABSTRACT}

\section{Introduction}

With the declaration of the Republic, one of the areas where change was felt strongly in the restructuring process was education. It is understood that the programs which are the essential elements of education are continually changing and developing. In the 2000s, developing technology and emerging scientific studies have also demonstrated the necessity of a new education program. Based on this requirement, teaching programs based on constructivist approach were implemented in 2004 and 2005, and teacher guidebooks were prepared for the teacher who is the practitioner of the program.

Teacher's guidebooks consist course plan and guide teachers on how to teach a lesson. In 2005, the Ministry of National Education, which was published in the Journal of Announcements No. 2551, published The Directive on the Planned Execution of Education and Training Activities, titled "Lesson Plan", No. 12. in the article, "If there is a teacher's guidebook for that course, guidebook is used instead of the course plan." was said. In 2004, the curriculum was implemented with a new understanding. Considering that the existing teachers were raised based on the previous program, the implementation of the program revealed the necessity of informing the teachers.

Teacher guidebooks, which were used from 2005 to 2017, have been removed from use since 2018-2019 academic year. This situation will affect the quality of teaching on teachers; it is a fact that there will be positive and negative aspects. The research was conducted in order to determine the positive and negative aspects of the use of the secondary school Turkish lesson teacher guidebooks in terms of preparation for the lesson, the course process, measurement and evaluation and the non-use of guidebooks. In the literature, it is seen that there are various researches about the Turkish teacher's guidebooks (Alkis Kucukaydin and Iscan, 2017; Bagci, 2010; Gocer and Akturk, 2015; Gocer and Sayin, 2014; Kurudayioglu and Orge Yasar, 2014; Yayli and Solak, 2014). These studies include the evaluation of the Teacher guidebooks from various perspectives. This study covers the positive and negative aspects of the use of the secondary school Turkish lesson teacher guidebooks in terms of preparation for the lesson, the course process, measurement and evaluation and the non-use of guidebooks. When we look at the researches on the subject, it is understood that the scope of our study is different from the studies conducted. The examination of a new situation and the current status of the study indicate the importance of the research.

\section{Method}

The research was conducted using the qualitative research method.. The case study is an in-depth description and examination of a limited system (Merriam, 2013). It creates a special method for collecting, editing, analyzing, and interpreting data and therefore represents a process of analysis and interpretation (Patton, 2002). The dismissal of the Turkish lesson teacher's guidebooks as of 2018-2019 Academic Year has been examined with the opinions of Turkish teachers. The study group consisted of 18 Turkish teachers working in the Ministry of National Education in Ordu in the 2018-2019 Fall Semester and participating in the study voluntarily. An appropriate sampling method (Creswell, 2013) was used for the determination of the study group. The study was carried out with permission from Ordu Provincial Directorate of National Education. A semi-structured interview form was used to collect the data of the research. Semi-structured interview form was obtained by taking the opinions of 3 field experts and 5 Turkish teachers. Preliminary interviews were conducted with the Turkish teachers who worked in the secondary schools of the Ministry of National Education in Ordu and volunteered to participate in the study. Then the semi-structured interview form was given to Turkish teachers. The opinions of the Turkish teachers were taken in writing two weeks later. The data obtained through the semi-structured interview form were transferred to the MAXQDA 12 qualitative data analysis program and analyzed using the content analysis technique. The basic process in content analysis is to bring together similar data within the framework of specific concepts and themes and to interpret them in a way that the reader will understand (Yildirim \& Simsek, 2013). Categorical analysis was used in the content analysis types. The data were coded before the categorical analysis. The themes were determined in semi-structured interview questions, and the coding was done with three field experts. Direct transfers were made from teacher opinions on the codes. The analyzed data was presented and interpreted with the visual images obtained through the MAXQDA 12.

\section{Findings, Discussion, and Results}

In the literature, it is seen that there are various researches about the Turkish teacher's guidebooks (Alkis Kucukaydin and Iscan, 2017; Bagci, 2010; Gocer and Akturk, 2015; Gocer and Sayin, 2014; Kurudayioglu and Orge Yasar, 2014; Yayli and Solak, 2014). The results obtained from the opinions of the Turkish teachers are presented below. 
Turkish teachers stated that the Turkish lesson teacher's guidebooks are useful in terms of course preparation, it is concluded that the guidebooks are useful in terms of planning and preparing lesson, but there are some negative effects like laziness. Turkish teachers expressed more opinions on the positiveness of the Turkish lesson teacher guidebooks. Turkish teachers stated that guidebooks contribute to providing teachers with the most control over the course, planning and creating convenience in terms of course process, but that guidebooks are negative in terms of limiting teachers Turkish teachers have expressed more views on the effectiveness of the guidebooks in terms of the course process. In terms of measurement and evaluation, it was seen that the guidebooks contributed to facilitating the teacher's job, giving feedback and follow-up, but it was concluded that the lack of adequately was negative. Turkish teachers have expressed more views on the positiveness of the guidebooks in terms of measurement and evaluation. It has been concluded that not using the guidebooks contributes to flexibility and leading to research, but that it has negative effects such as increased workload, lack of teaching unity. Turkish teachers expressed more opinions on the negativity caused by not using guidebooks. When these results are examined in general, a positive view comes to the forefront in the use of secondary Turkish language teaching teacher's guidebooks. Turkish teachers have also stated the negative aspects of the guidebooks, but they have more focused on the positive aspects.

Based on the results of the study, it is suggested that the use of books is more appropriate, rather than removing the use of the Turkish lesson teacher's guidebooks. 